\title{
Gendericide: A scary truth
}

\section{Shrestha NS}

Assistant Professor, Department of Obstetric and Gynaecology, Kathmandu Medical college, Sinamangal, Nepal.

$F_{b}^{e}$ emale infanticide is the intentional killing of baby girls and female foeticide is aborting female foetuses before they are born. The phenomenon of female infanticide is as old as some of the cultures. However female foeticide was rare before the late 20th century, because of the difficulty of determining the sex of the foetus before birth, but ultrasound and other sophisticated tests has made such selection easier. Female foetuses are aborted in alarming numbers in some countries mainly in East Asia and South Asia because girls are not valued as highly as boys. In fact, girls are disvalued, and it is regarded as bad fortune to bear a daughter, and good fortune to bear a son. The reason for this gender bias is mainly cultural and financial. In these countries sons traditionally look after their parents, while daughters end up joining another family, and looking after the elderly people in that family perhaps, because of this, parents in India must pay heavy dowries when their daughters marry. Girls are a financial liability there. Thus, as a result girls in this patriarchal and male dominated society are systematically discriminated, and the discrimination starts right from the womb.

Women are missing in millions - aborted, killed, or neglected to death. In 1990 an Indian economist, Amartya Sen had put the missing girls number at 100 million $^{1}$; the toll is higher now. Performing sex determination ultrasound scan and sex selective foeticide is illegal in most of the countries including Nepal but it is easily done. It is estimated that in India nearly a million baby girls are aborted each year and in China by the year $2020^{2}$, there will be 30 million more men than women according to a report by the state population and Family Planning Commission ${ }^{3}$. The exact data of female foeticide from Nepal is not yet available but estimates indicate that more than 200,000 females are "missing" from Nepal and the problem is on the rise $\mathrm{e}^{4}$. The reason behind this rising trend is the modern desire for a small family with easy access to ultrasound scanning to determine the sex of the foetus and preference for male child. Sex selection is violation of law and unethical. But our patriarchal society continues to turn a blind eye towards it. The situation is further worsened by lack of awareness of women's rights and by the indifferent attitude of governments and medical professionals. In Nepal, the available legislation for prevention of sex determination needs strict implementation, alongside the launching of programmes aimed at altering attitudes, including those prevalent in the medical profession.

Achieving gender equality is one of the United Nation's Millennium Development Goals (MDGs) set for 2015, and Nepal will have to address the issue of heinous crime committed against female in the form of foeticide, infanticide, and neglect, in order to achieve millennium development goal. Prenatal sex determination with the intention of preventing female births must be viewed as a manifestation of violence against women, a violation of their human right.

This trend of sex selection is extremely unhealthy and can have disastrous consequences for society. Moreover, a society which denies the girl child even the basic right to existence cannot claim to be civilized. A girl child has all the right to be born, to live, and to be loved. It is time for the government to take some serious steps to stop this serious act of crime against women by so called 'civilized' society. It is time for the women right activists to do some advocacy and bring awareness to this silent gendericide. It is time for every responsible individual to raise voice against this cold blooded murder.

\section{References}

1. Sen A. More Than 100 Million Women Are Missing. New York Review of Books. 1990; $37(20)$.

2. The Sunday Times [homepage on the Internet]. [updated 2010; cited on 2010]. Gender genocide. Available from: http://www.thesundaytimes. co.uk/sto/public/sitesearch.do?querystring $=\% \mathrm{E}$ 2\%80\%9CGender+genocide $\%$ E2\%80\%9D.+\& sectionId $=2 \& p=$ sto $\& p f=$ all

3. BBC news [homepage on the Internet]. [updated 2007; cited 2010]. Chinese facing shortage of wives. Available from: news.bbc.co.uk/1/hi/ world/asia-pacific/6254763.stm

4. Milner LS. Hardness of heart/hardness of life: the stain of human infanticide. Lanham, New York, Oxford: University Press of America, 2000. P. 223. 